\title{
Practical strategies to teach vocabulary through games in EFL beginner classes: the case study of some secondary schools in Namangan region
}

\author{
Zebo Botirova Hakimjon qizi ${ }^{1}$, Islomjon Umrzoqov Israilovich ${ }^{2}$

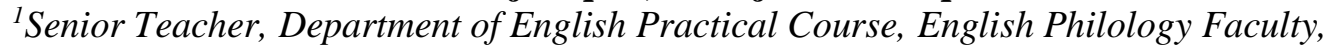 \\ Namangan State University of Namangan State University, Uzbekistan \\ ${ }^{2}$ Senior Teacher, Department of English Language and Literature, English Philology Faculty, \\ Namangan State University, Uzbekistan
}

Email:botirova_z@umail.uz

\begin{abstract}
One of the difficult aspects of learning a foreign language, particularly in an EFL context, is vocabulary teaching and learning. This article investigates the difficulties faced by EFL teachers and their learners in the process of teaching and learning English language .It aims at exploring the motivating potential of games in improving the teaching and learning vocabulary in EFL beginners' classes in Uzbek secondary schools.
\end{abstract}

Keywords: syllabus, vocabulary, game, method.

\section{INTRODUCTION}

Nowadays English is an important medium that helps people to interact.In teaching and learning settings, studentsare constantly motivated to master English language and its related skills in order to be able to benefit by the various opportunities offered by the globalization.Moreover,English is needed in many fields to support a number of activities in which people speaking a variety of languages are involved. Due to its importance, In Uzbekistan,introduced teaching of English as a Foreign Language in the national syllabus at primary, secondary and university levels.In spite of the Uzbek government effort to improve the teaching of EFL, teachers, school authorities and parents often complain about the EFL learners' poor achievement in different language skills. For instance,they report that learners show a limited ability to understand new words and that one of the major reasons behind such a limitation is their poor vocabulary reservoir and their lack of efficient strategies to understand new words or structures. Consequently, after attendingEFLlanguage classes for years and even passing written language exams, a lot of students can hardly string a sentence together in an oral communication. Teaching English to Uzbek speaking students, especially EFL beginners [students of 6 th and $5^{\text {th }}$ form of secondary schools] is not easy because it is a new language for them to learn. As a result, the interest of students in learning English is needed as the key to make it easierfor themto master how to speakit. Teachers should have effective and efficient techniques to introduce English to them so that the beginner learners will be interested and motivated to learn English. There are a lot of ways to introduce English to EFL beginners. One of these techniques is through games. As a matter of fact, Children like playing games, so by using games as a teaching method, beginner learners become more interested in learning English. Games are not only for fun but also for motivating students to communicate in English fast and easily. Learning by playing games is a good way to make students understand easily English language for in doing fun activities by themselves, they will find it easy to remember and learn about the materials taught by their teacher.

In addition, many textbooks and methodology manuals writers have argued that games are not just time filling activities but have a great educational value. Lee [1979:2] holds that "most of languages games make learners use the language instead of thinking about learning the correct form". According to him, "games should be treated as central not peripheral to the foreign language teaching program".

Teaching Vocabulary to Beginner Learners by Using Games

Volume 2, Issue VI, Dec 2019|94 
Learning is one of the primary activities of students in the classroom. Successful learning is only on the right way to lead the process. Good learning atmosphere and method can guide the students to learn more and meaningful. To accomplish such condition, teachers must create variety type and attractive methods for the class. What should a teacher do if theirstudents get bored? Using a variety type of games can be an alternative solution to handle this problem. Through this work I want to share experiences about how to teach English vocabulary by using games. There is a common perception that all learning should be serious and solemn in nature and that if one is having fun and there is hilarity and laughter, then it is not really learning. This is a misconception. It is possible to learn a language as well as enjoy oneself at the same time. One of the best ways of doing this is through games. Many experiences textbook and methodology manuals writers have argued that games are not just time filling activities but have a great educational value. W. R. Lee holds that "most of language games make learners use the language instead of thinking about learning the correct form" [1979:2]. He also says that games should be treated as central not peripheral to the foreign language teaching program. A similar opinion is expressed by Richard -Amato, who believes games to be fun but warns against overlooking their pedagogical value, particularly in foreign language teaching. According to him "Games can lower anxiety, thus making the acquisition of input more likely" Richard-Amato, [1988: 147]. "They are highly motivating and entertaining, and they can give shy students more opportunity to express their opinions and feelings' 'Hansen, [1994: 118]. They also enable learners to acquire new experiences within a foreign language which are not always possible during a typical lesson.

\section{ANALYTICAL BACKGROUND}

Vocabulary should be mastered by the beginner learners so that they will be easy to understand the language. The way to help them in learning vocabulary is by having a good method in teaching. The teacher should have a creative way in giving the materials to the students; one of the ways is by doing some fun activities. "Children play and children want to play. Children learn through playing. In playing together, children interact and in interacting they develop language"Brumfit, [1995:142]. Similarly, Virginia in her book Techniques in Teaching vocabulary said that there is truth in the belief that experience is the best vocabulary teacher According to [Harmer, 1991:7], "at the same time children's span of attention or concentration is less than adults. Children need frequent changes of activity: they need activities which are exciting and stimulate their curiosity: they need to be involved in something active [They will usually not sit and listen]. According to Khan [1991], "games are activities governed by rules, which set up clearly defined goals". Games consist of fantasy, ritual, competition, and luck that are interesting for children. These things make games enjoyable. It means games reduce boredom. When games are used, the situations of classroom become alive and natural. Games create situations that make children's need and want to use English. Lee [1994] explained that it occurs because in games language is linked by action. Thus, games are appropriate to the principal of language accompanying action. As a technique of teaching games involve children actively. Through games, all children can get the opportunity to succeed in learning. Children are very fond of games. If they learn through games, they will enjoy and relax in learning. As stated by Paul [2003:49], "they will take what they learn through games and use it in daily life". Besides that, games have comfortable environment, so that they will be able to take a risk and try something new. Teachers need to use games that students like and they do not use too many or too few kinds of games. Too many kinds of game will make them focus on games, not English. Too few games will make the game too predictable so that the games are not challenging. Based on the statements above, we can say that in teaching vocabulary the teacher should be able to create some various fun activities. The aim of that way is to make the student easier in understanding the materials and easier in memorizing the new words. Through experiences with situations in which a language is used by the student, they will be easy to learn and used the language. Besides, we also know that young learners have a high curiosity in learning something new. But they will be able to get bored easily if there is the same method in teaching. So the various kinds of fun activities are needed to attract them and increase their attention in learning English. By those opinions above, it can be concluded that games as "the teaching devices" are perceived as mere time-fillers, "a break from the monotone of drilling" or playful activities. I recognize that many teachers often overlook the fact that in a relax atmosphere, real learning takes place, and students use the language they have been exposed to and have practiced earlier. 
A game is structured playing, usually undertaken for enjoyment and sometimes used as an educational tool. Games are distinct from word, which is usually carried out for remuneration, and from art, which is more often an expression of esthetical or ideological elements. "Games are a form of teaching which may be used in circumstances where ordinary approaches are not well tolerated; when attention is hard to get and harder to keep' [Nicolson and Williams, [1975:1]

Many experienced tests books and methodology manuals writers have argued that games are not just time-filling activities but have a great educational value. W. R. Lee holds that must language games make learners use the language instead of shopping about learning the correct forms [1979:2]. He also said that games should be treated as a central not peripheral to the force of the foreign teaching program. There are many advantages of using games. «Games can lower anxiety, thus making the acquisition of input more likely" [Richard-Amato 1988:147]. They are highly motivating and entertaining, and they can give shy student more opportunity to express their opinions and feelings [Hansen 1994:1 18]. They also enable learners to acquire new experiences within a foreign language which are not always possible during a typical lesson. Furthermore, to quote Richard-Amato, they, "add diversion to the regular classroom activities", break the ice, "but also they are used to introduce new ideas" [1988: 147]. In the easy, relaxer atmosphere which is created by using games, student remember things faster and better [Wierus and Wielus 1994:218]. S. M. Silvers says many teachers are enthusiastic about using games as "a teaching device" yet they often perceive games as more time-fillers, "a break from the monotony of drilling" or frivolous activities. He also claims that many teachers often overlook the fact that in a relaxed atmosphere, real learning takes place, and student use the languages have been exposed too and have practiced earlier [1982:2]. “Games encourage, entertain, teach, and promote fluency”. If not for any of these reasons, they should be used just because they help student see beauty in a foreign language and not just problems that at times seem overwhelming.

\section{CONCLUSION}

In Uzbekistan, learning vocabulary has been considered as a boring subject for a long time and the traditional way of learning vocabulary by mere copying and remembering has shown to be less than effective. It is believed by a large majority of EFL teachers in Uzbekistan Republic that games are just used for fun and they have very little effect in teaching and learning. However, an important number of research works shows that games can be used to improve EFL learner vocabulary. The goal of this article is to point out the difficulties faced by EFL teachers and their learners in vocabulary teaching and learning process so as to find out the practical strategies for using games to improve EFL learners 'lexical background.

To overcome the problems identified in the course of the present investigation, government are recommended to provide a well training for EFL teachers, provide the appropriate modern teaching and learning materials for schools, revise the time allotted to the English teaching, recruit teachers and set up English clubs in primary and secondary schools. Teachers should innovate and create different fun activities in order to make their classes more interesting and enjoyable.

\section{REFERENCES}

1. Brown, H. D.(2000). Principle ofLanguageTeachingandLearning.New York: Pearson Education.

2. Brown, H. D. (2001). AnInteractiveApproach to LanguagePedagogy. New York: Pearson Education.

3. Paul, D. (2003).TeachingEnglishtoChildren in Asia.HongKong: Longman. Scott

4. Ellis, R. (2005). “Principles of Instructed Language Learning”.Asian EFL Journal. Retrieved February 12, (2006)

5. Johnson, D. W. \& Al (2000). "CooperativeLearningMethods": A Meta-analysis. CooperativelearningCenter, University of Minnesota.Retrieved February 12, (2006) 